\title{
Multi-phase Microstructures and Their Properties in High Strength Low Carbon Steels
}

\author{
Anthony J. DeARDO \\ Basic Metals Processing Research Institute, Department of Materials Science and Engineering, University of Pittsburgh, PA \\ 15261, U.S.A.
}

(Received on February 15, 1995; accepted in final form on April 24, 1995)

\begin{abstract}
It has been known for some time that steel microstructures are almost always composed of mixtures of phases and microconstituents. It has also been recognized that the minor phase can often exert a major influence on the final mechanical properties of structural steels. Over the last two decades, several important advances have been made in terms of the properties which have become attainable in these steels. These advances have occurred largely through a better understanding of the control of multi-phase microstructures. This paper reviews the benefits that have accompanied a better understanding of these complex microstructures.
\end{abstract}

KEY WORDS: multi-phase; microstructure; HSLA; microalloying; thermomechanical processing; transformation; mechanical properties; formability; precipitation.

\section{Introduction}

When the microstructures of steels are discussed, they are usually described as being ferritic, bainitic or martensitic. However, it is well-known that these microstructures are often, if not always, complex and heterogeneous in nature. Even when precipitates and non-metallic inclusions are disregarded, the remaining matrix is often found to be composed of a mixture of phases and microconstituents. Whether the matrix is predominately ferrite, bainite or martensite, it is rare if there is not at least one or two additional phases or microconstituents present in minor amounts. There are cases where the presence of the minor phases or microconstituents are apparent and well-documented, e.g. pearlite in ferrite-pearlite hot rolled steels, and martensite in dual-phase steels. In these cases, the presence of the minor microconstituent in the multi-phase matrix microstructure is known to have a very powerful effect on the final properties of fairly low strength flat rolled steels.

Perhaps less well-known and appreciated are the multi-phase microstructures that can be generated in essentially bainitic or martensitic high strength plate steels through controlled rolling followed by heat treatments that include intercritical aging. In this case, small amounts of phases newly formed during intercritical aging have been found to have a dramatic effect on both the strength and the resistance to cleavage of these steels. In the presence of this effect, these steels offer a spectacular package of strength and toughness properties in heavy sections. On the other hand, in the absence of this effect, these steels would be of rather limited usefulness.

Possibly even less well-known is the mixture of autotempered martensite and lower bainite sometimes found in low carbon, low alloy steels. When these steels exhibit a multi-phase mixture of about $85 \%$ martensite and $15 \%$ lower bainite, and having transformed from a well-conditioned austenite, their resulting properties are quite impressive.

Finally, the concepts of multi-phase metallurgy do not apply only to the steel matrix. Recent work has shown that the precipitation responsible for the stabilization of carbon in ultra-low carbon sheet steels for deep drawing applications can be multi-phase in nature. In steels with high sulfur contents, the stabilization occurs by the in-situ transformation of TiS to $\mathrm{Ti}_{4} \mathrm{C}_{2} \mathrm{~S}_{2}$ and not by the direct precipitation of either $\mathrm{Ti}_{4} \mathrm{C}_{2} \mathrm{~S}_{2}$ or TiC. Multi-phase precipitates, containing both $\mathrm{TiS}$ and $\mathrm{Ti}_{4} \mathrm{C}_{2} \mathrm{~S}_{2}$, are observed in these steels and represent the partial transformation of TiS. This observation calls into question the philosophy of the alloy design of the so-called IF steels currently being used.

The purpose of this paper is to review several types of steels with multi-phase microstructures and to show how the final mechanical properties of these steels can be enhanced by the proper control of the final microstructure.

\section{The Early Ferrite-Pearlite Steels}

Pearlite was perhaps the first microconstituent shown to have a large effect on properties, even when present in rather small amounts. As early as 1935, the influence of the pearlite content on strength and ductility were 


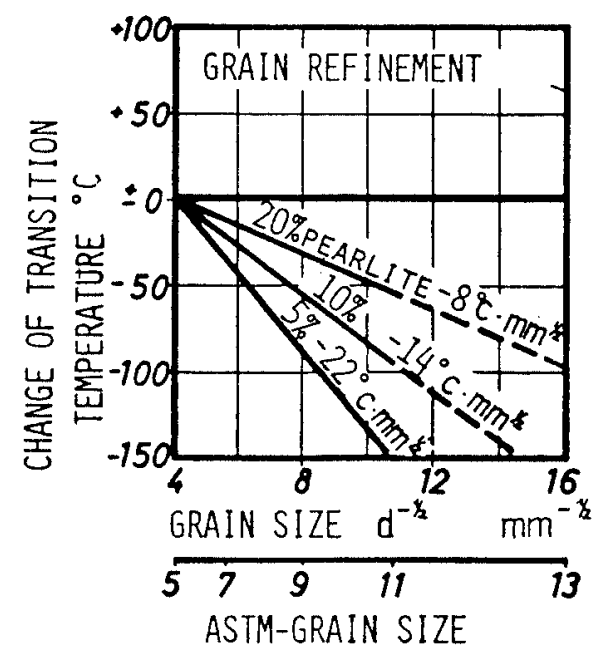

Fig. 1. Change of transition temperature through variation of the structure of the steel..$^{5)}$

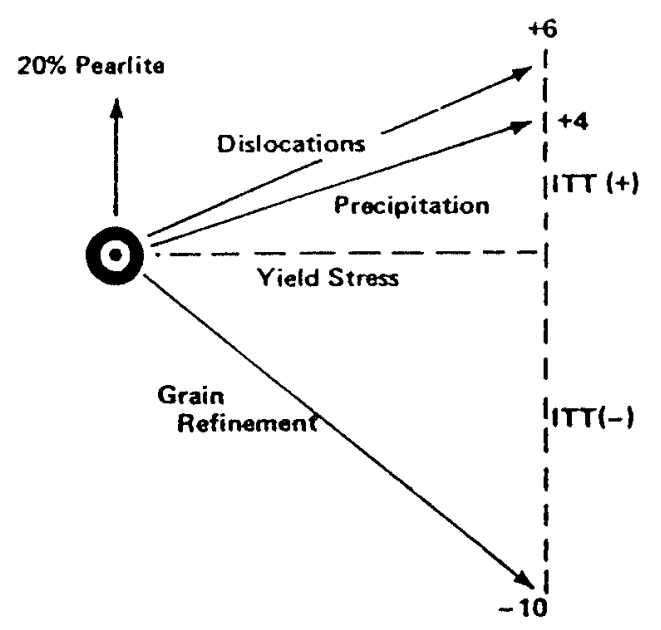

Fig. 2. Effect of strengthening mechanism on the impact transition temperature. ${ }^{6}$

conclusively shown, ${ }^{1}$ and by 1937 the effect of carbon content and pearlite on strength, ductility and notch toughness were clearly recognized. ${ }^{2)}$ In more modern times, the effects of pearlite were measured on properties of technological interest to the end user. For example, pearlite was recognized as early as 1970 as contributing to the deterioration in the resistance to both ductile and brittle fracture in notched impact tests in hot rolled linepipe steels. $^{3-5)}$ Of particular significance was the surprisingly strong negative influence of pearlite on the FATT, even in the presence of significant grain refinement. ${ }^{5)}$ Early examples of quantitative relationships between the amount of pearlite and toughness are shown in Figs. 15) $^{5}$ and 2. ${ }^{6}$

The negative influence of pearlite or carbon content on weldability in linepipe steels has also come to be well-recognized. ${ }^{7-9)}$ This was especially true for the heat-affected zones (HAZ) associated with multi-pass arc welding which employed fusible electrodes, a technology widely used since World War II. The carbon content of the base plate has been shown to responsible for both poor weldment structural integrity, i.e. cold cracking of the HAZ ${ }^{8)}$ and poor toughness of the HAZ. ${ }^{9}$ These two effects are clearly observed in Figs. ${ }^{8)}$ and $4 .{ }^{9)}$

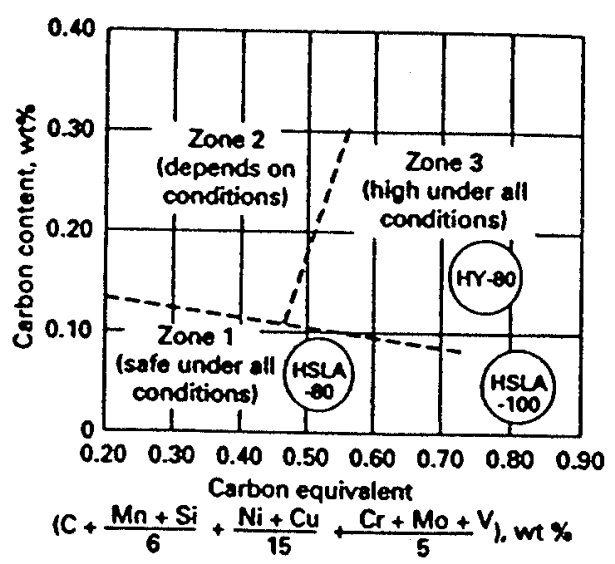

Fig. 3. Effect of steel composition on the susceptibility of the heat affected zone (HAZ) to cold cracking for HY-80, HSLA-80, and HSLA-100 steels. ${ }^{8)}$

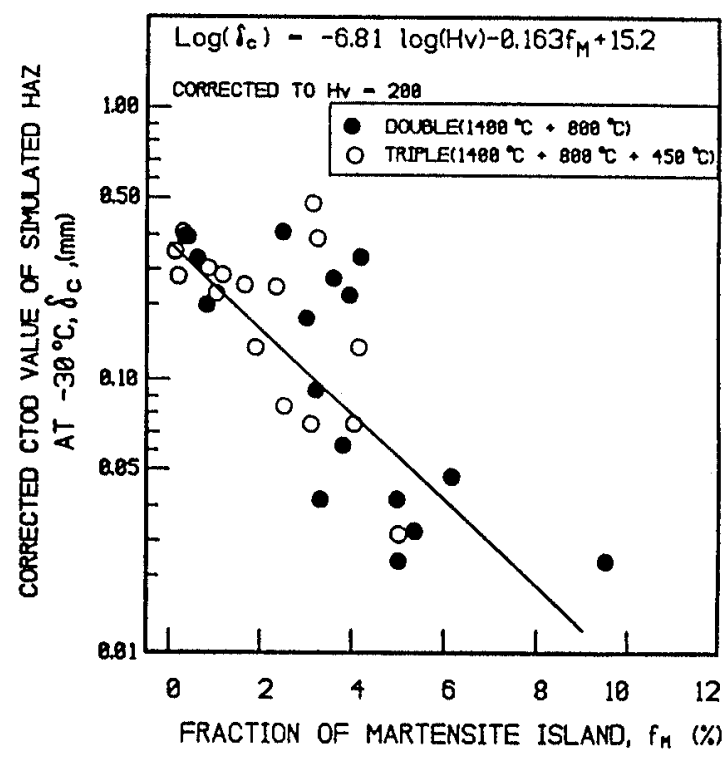

Fig. 4. Toughness of HAZ as a function of the fraction of martensitic island. ${ }^{9)}$

Since ductility and formability are very important in strip and sheet steels, the influence of carbon or pearlite content on these properties was also closely examined, especially in steels at high strength, i.e. high pearlite, levels. Once again, pearlite was found to be detrimental to properties such as ductility. ${ }^{1,2,6)}$

The scenario existing for high strength hot rolled steels in the mid-1960's was not very pleasant. The pearlite needed for strengthening was responsible for lowering several other critical properties such as ductility, toughness and weldability. The response to this dilemma led to a large research effort whose goal was to find ways of lowering the carbon content of the steel while still maintaining high strength, i.e. finding substitute mechanisms for the composite strengthening of pearlite. During the decade ending with 1975 , the metallurgical principles were developed which eventually led to the combination of controlled rolling and microalloying. The success of this concept, described in a series of international conferences meant that from that time onward, carbon was no longer requisite for strength. 


\section{The Multi-phase Strip and Sheet Steels}

The next example of where a minor microconstituent had a major effect in multi-phase steels originated as a response to the oil embargo of the early 1970's. The automobile industry recognized that it was obviously possible to save weight by substituting higher strength steel for lower strength steel. Unfortunately, the stretch formability of the high strength, hot rolled microalloyed steels was not adequate for the intended applications. This problem was resolved by the discovery of the dual-phase steels for either hot band ${ }^{10)}$ or cold rolled ${ }^{11)}$ applications. In simple terms, dual-phase steels were modified ferrite-pearlite steels in which the pearlite had been converted to martensite by intercritical annealing followed by cooling to room temperature. The physical and mechanical metallurgy of these steels were reviewed in several symposia. ${ }^{12,13)}$

A typical dual-phase steel contained about $15 \mathrm{vol} \%$ martensite. When compared to a similar high strength ferrite-pearlite steel, the presence of the martensite resulted in a lowering of the yield strength, an increasing of the tensile strength and, in extraordinary fashion, in also an increasing of the total elongation and stretch formability. An example of this comparison is shown in Fig. 5. ${ }^{11)}$ The enhanced ductility and stretch formability exhibited by the dual-phase steels has been attributed to: (i) the nature and behavior of the martensite, i.e. its ductility and cohesiveness with the ferrite, ${ }^{14)}$ (ii) the low carbon contents in the ferrite following slow cooling from the intercritical annealing temperature, ${ }^{15}$ ) and (iii) the transformation of retained austenite. ${ }^{16)}$

The as-heat treated dual-phase steels stand in stark contrast to the ferrite-pearlite steels concerning the influence of the minor phase. Whereas the pearlite was responsible for the degradation of several important properties in the ferrite-pearlite steels, the martensite was responsible for several beneficial effects in the dualphase steels.

It should be noted that it was also possible to form a multi-phase microstructure in the as-hot rolled condition. ${ }^{17-20)}$ The physical metallurgy of as-rolled multi-phase steels is as complex as it is fascinating, involving the proper austenite conditioning, $\mathrm{CCT}$ diagram and processing schedule. A schematic example of the appropriate features is shown in Fig. 6. ${ }^{17)}$ It is clear that parameters such as composition, finishing temperature, cooling rate, and coiling temperature could all influence the final microstructure which, itself, could be composed of ferrite, bainite, martensite, and retained austenite. Using the laboratory simulation shown in Fig. 6, and employing a steel of nominal composition $1.25 \mathrm{Mn}-1.0 \mathrm{Si}-0.4 \mathrm{Mo}-0.6 \mathrm{Cr}$, the influence of carbon content on the final microstructure is shown in Fig. 7, ${ }^{17)}$ and on final properties in Fig. $8,{ }^{17)}$ The best properties are found near $0.06-0.08 \mathrm{wt} \% \mathrm{C}$, where the final microstructure is actually quadruple-phase in nature.

Later work illustrated how the final microstructure could be manipulated by using more complex controlled accelerated cooling. ${ }^{19)}$ An example is shown in Fig. 9. ${ }^{19)}$ The influence on the amount of low temperature transformation products (LTTP) of the starting temperature of accelerated cooling $\left(T_{3}\right)$ and the two cooling rates $\left(C_{1}\right.$ and $\left.C_{2}\right)$ are shown in Figs. 10 and 11, respectively. ${ }^{19)}$ This work shows that it is possible to

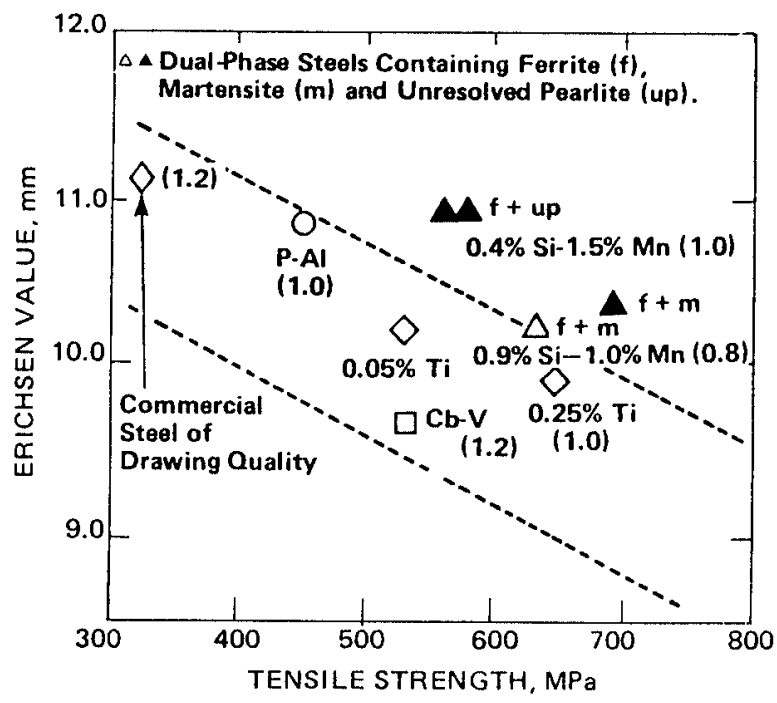

Fig. 5. Relation between tensile strength and Erichsen value for various high-strength, cold-rolled steels. The thickness of each steel is in parenthesis. ${ }^{11)}$

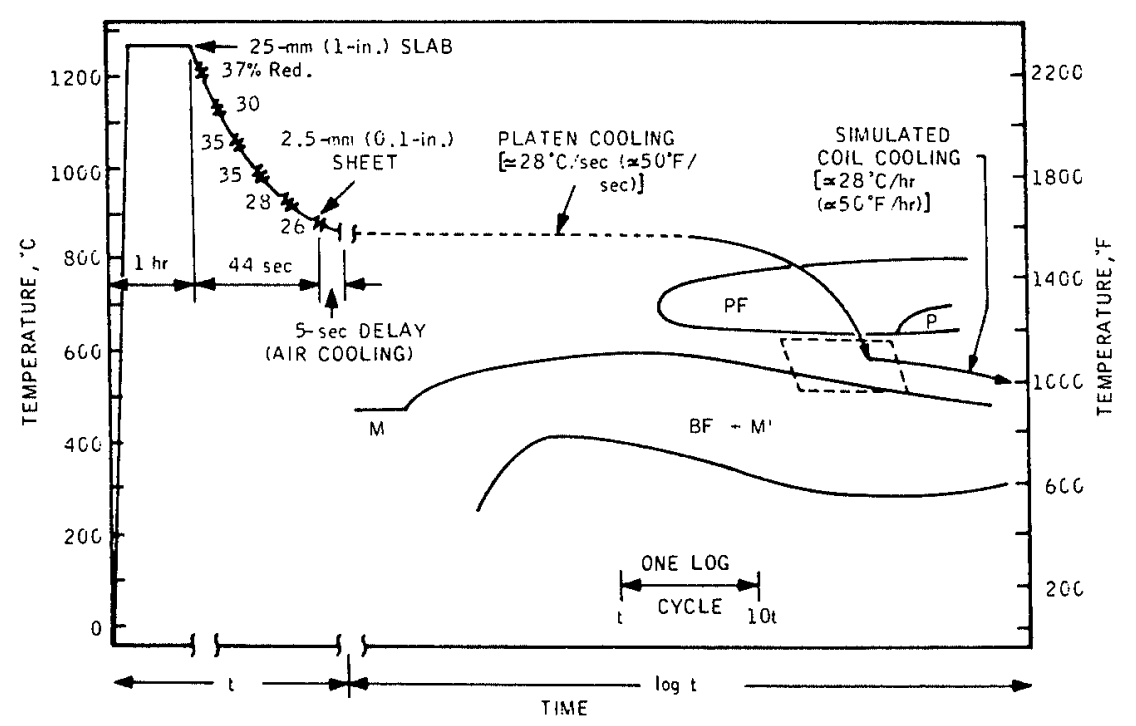

Fig. 6.

Schematic representation of laboratory simulation of hot-strip mill process. ${ }^{17)}$ 


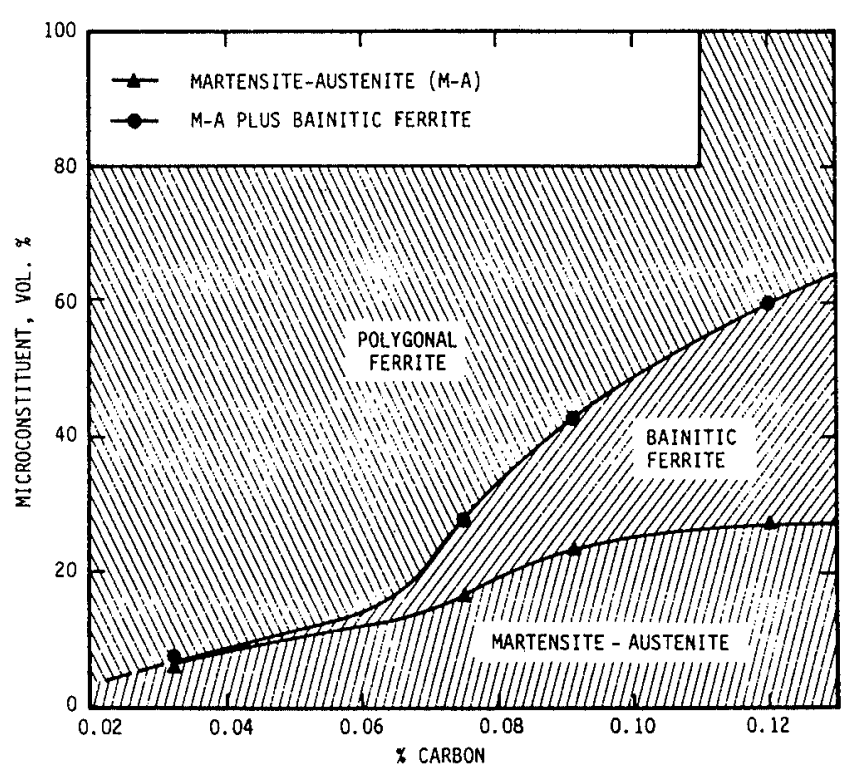

Fig. 7. Effect of carbon content on microconstituent proportions in laboratory steels simulated coiled at $595^{\circ} \mathrm{C}$ $\left(1100^{\circ} \mathrm{F}\right){ }^{17)}$

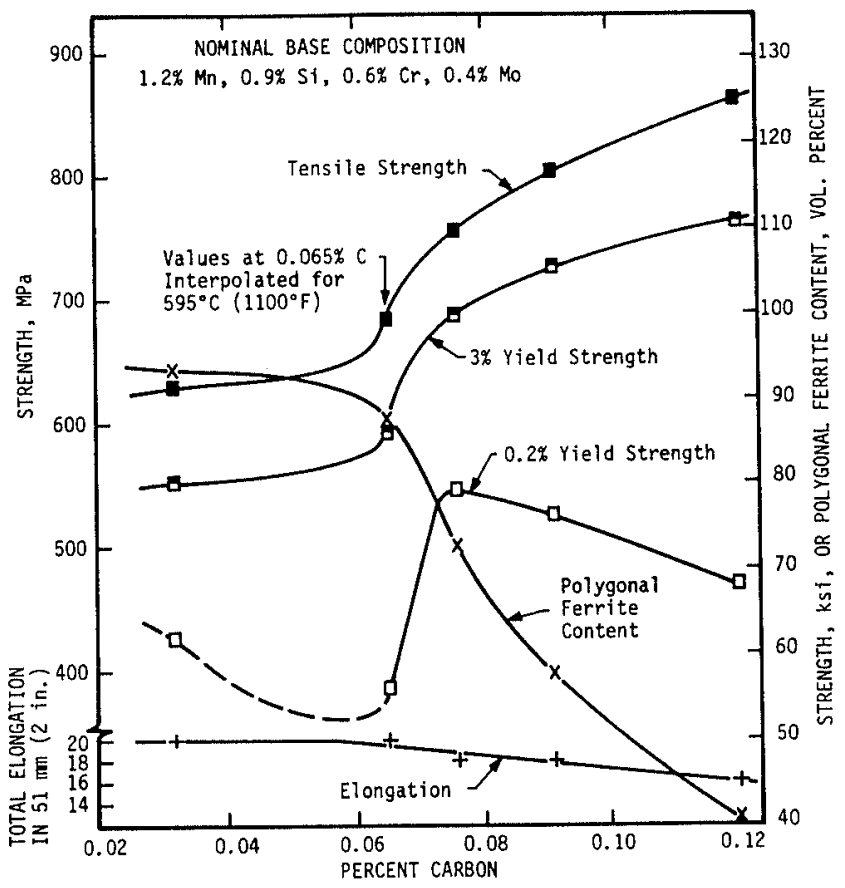

Fig. 8. Effect of carbon on polygonal ferrite content and tensile properties of laboratory steels simulated coiled at $595^{\circ} \mathrm{C}\left(1100^{\circ} \mathrm{F}\right),{ }^{17}$

exert substantial control over the final microstructure and properties through creative alloy design and processing.

The multi-phase strip and sheet steels discussed above were intended for applications where tensile strengths near $700 \mathrm{MPa}$ were required. Recent work has shown that these concepts concerning the LTTP can be extended to much higher strength levels while retaining good ductility. ${ }^{21)}$ This work has shown that yield and tensile strengths of 420 and $1120 \mathrm{MPa}$, respectively, could be achieved, along with uniform elongations of $25 \%$.

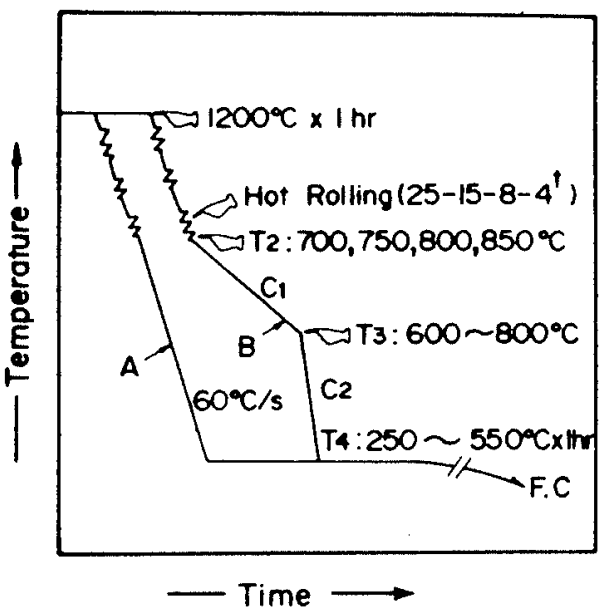

Fig. 9. Schematic representation of hot rolling and controlledcooling process. ${ }^{19)}$

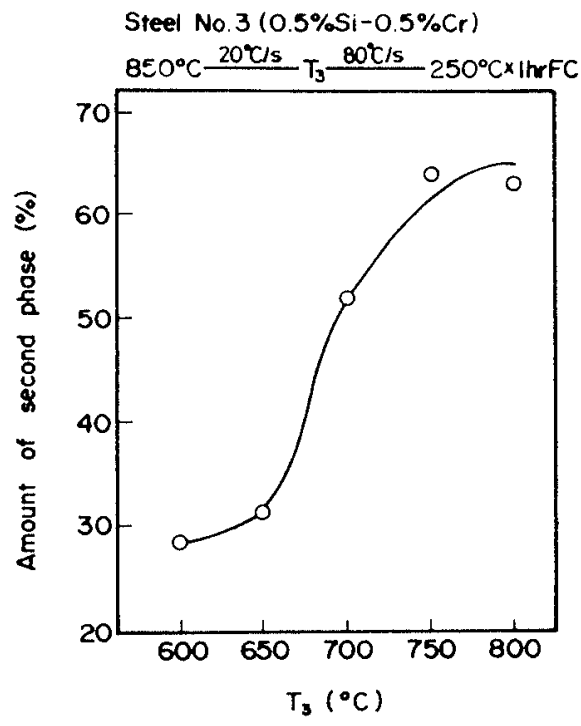

Fig. 10. Relationship between low temperature transformation products contents and starting temperature of accelerated cooling $\left(T_{3}\right) \cdot{ }^{19)}$

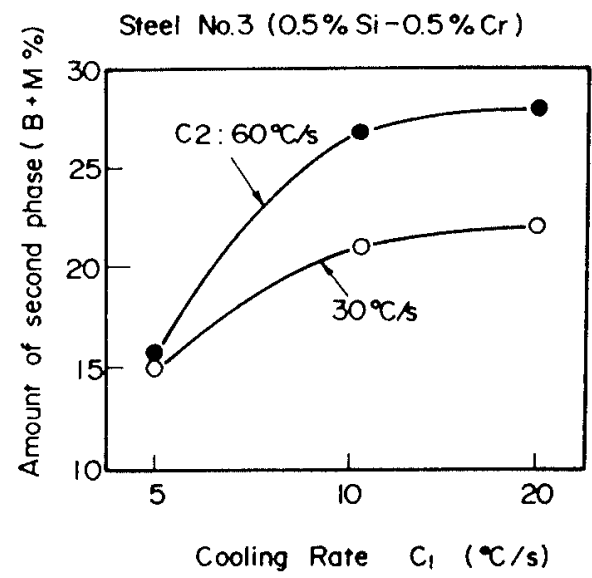

Fig. 11. Relationship between low temperature transformation product and cooling rate $C_{1}$ and $C_{2} \cdot{ }^{19}$ )

\section{Multi-phase Plate Steels}

It is extremely difficult, if not impossible, to obtain yield strengths in excess of $550 \mathrm{MPa}$ in ferrite-pearlite microalloyed microstructures in thicknesses typical of linepipe grades, e.g. $18 \mathrm{~mm}$, even with controlled roll- 
Cherpy V-notch toughness at $-20 \propto \mathrm{C}$ (J)

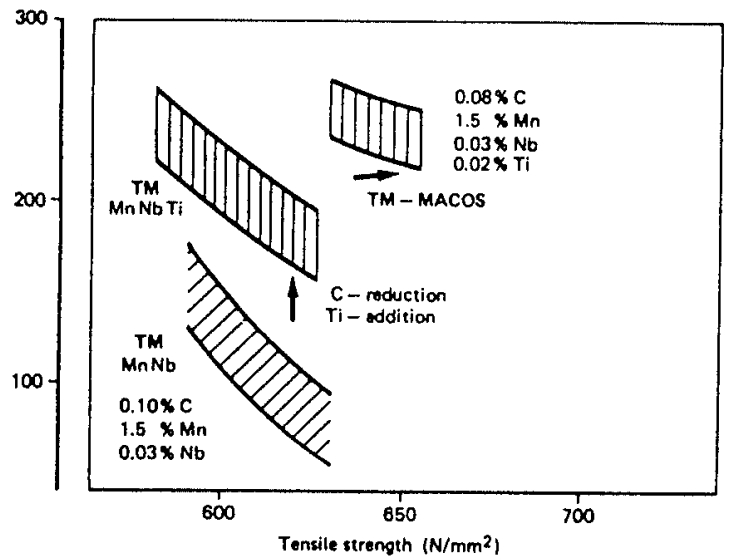

Fig. 12. Development of $\mathrm{MnNb}$-steels through additional micro-alloying with titanium and the use of TMMACOS. ${ }^{23)}$

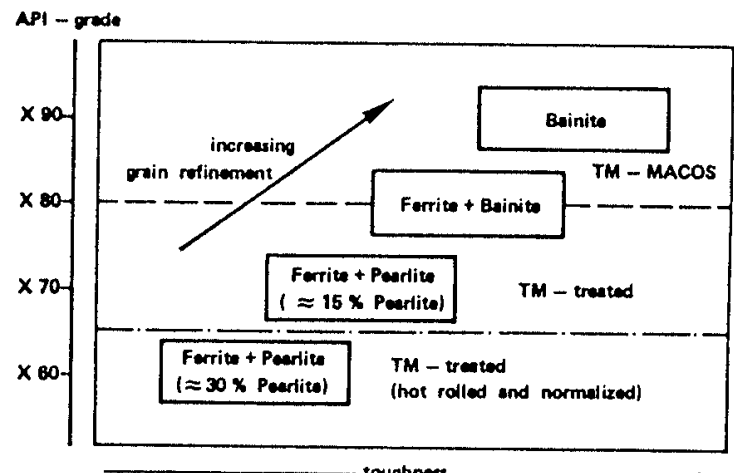

Fig. 13. Microstructure and mechanical properties. ${ }^{24)}$

ing and precipitation hardening. The combination of controlled rolling, accelerated cooling, and increased hardenability led to mixed microstructures consisting of ferrite and lower bainite which were able to achieve this goal. The higher strengths found in these multi-phase plate steels have been attributed to a combination of: (i) a fine dispersion of bainite, (ii) significant grain refinement of the ferrite, (iii) very effective precipitation hardening, and (iv) very high dislocation densities in the ferrite. ${ }^{22)}$ A very informative historical review of this technological evolution is shown in Fig. 12, ${ }^{23)}$ for compositional changes, and in Fig. $\mathbf{1 3},{ }^{24)}$ for processing changes. In this case, changing from a ferrite-pearlite to a multi-phase microstructure has resulted in the ability to achieve higher strengths in as-rolled steels.

Another example of where multi-phase metallurgy has been of substantial benefit was demonstrated during the development of HSLA-100 for plate applications, especially for surface ship and submarine construction. The reason that this steel was developed was to reduce both the cost of and time required for fabrication, i.e. welding. Both the historical account of the development of this steel and the rationale behind it have been described previously. ${ }^{25}$ In essence, HSLA-100 was developed to replace the HY-100 steels, mainly because the HSLA-100 steel was considered to have better weldability. A composition typical of HSLA-100 steel is shown in Table 1.

The ultra-low carbon content of HSLA-100 should
Table 1. Composition of HSLA-100 steel. (wt $\%$ )

$\begin{array}{llllllllllll}\mathrm{C} & \mathrm{Mn} & \mathrm{Ni} & \mathrm{Cr} & \mathrm{Cu} & \mathrm{Mo} & \mathrm{Nb} & \mathrm{Si} & \mathrm{Al} & \mathrm{N} & \mathrm{P} & \mathrm{S}\end{array}$

$\begin{array}{llllllllllll}0.036 & 0.91 & 3.59 & 0.59 & 1.60 & 0.59 & 0.025 & 0.24 & 0.022 & 0.097 & 0.008 & 0.005\end{array}$

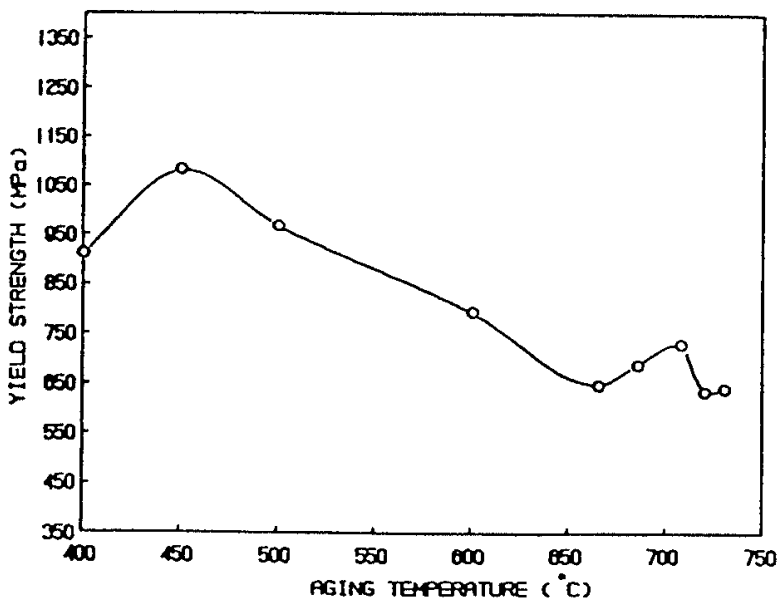

Fig. 14. Variation of yield strength with aging temperature of as-quenched HSLA 100 steel. $^{27)}$

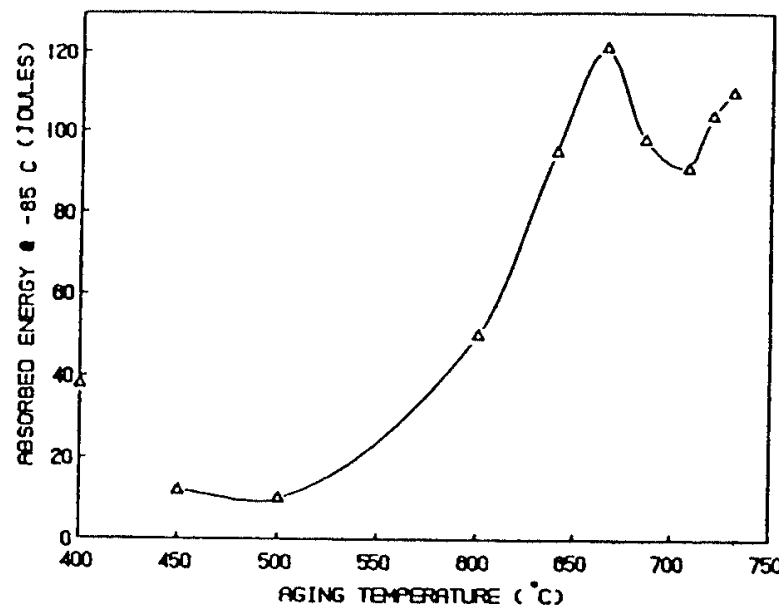

Fig. 15. Effect of aging temperature on impact toughness at $--85^{\circ} \mathrm{C}$ for HSLA 100 steel ${ }^{26,27)}$

result in reduced or eliminated cold cracking, Fig. 3, and good HAZ toughness, Fig. 4. What is particularly impressive about HSLA-100 is that it exhibits excellent mechanical properties in heavy guages after reheating, quenching and aging following hot rolling. When the steel is aged to $700 \mathrm{MPa}$ yield strength, the toughness at $-85^{\circ} \mathrm{C}$ is very high in both the standard Charpy V-notch $(\mathrm{CVN})$ and full-size dynamic tear tests in plate thicknesses ranging to $100 \mathrm{~mm}$.

Much interest has been focussed on the role played by the copper in these steels. These steels are, in fact, often described as being copper precipitation hardened. A rather extensive research program is being conducted to better understand why these steel have such good low temperature toughness, and what is the role of copper in achieving this impressive strength-toughness balance. ${ }^{26,27)}$ What follows is a brief summary of that work. When the steel described in Table 1 is controlled rolled, reheated to $900^{\circ} \mathrm{C}$, quenched and aged, the yield strength and $\mathrm{CVN}$ toughness at $-85^{\circ} \mathrm{C}$ were observed to vary 
with aging temperature as shown in Figs. 14 and 15, respectively. ${ }^{26,27)}$ Perhaps the best balance of yield strength $(720 \mathrm{MPa})$ and toughness $\left(95 \mathrm{~J}\right.$ at $\left.-85^{\circ} \mathrm{C}\right)$ properties was achieved by aging at $640^{\circ} \mathrm{C}$.

Detailed studies using TEM and STEM revealed that the increase in low temperature toughness observed when aging took place between 620 and $720^{\circ} \mathrm{C}$ was a result of new austenite that was formed during aging. This austenite, formed during intercritical aging, appeared to increase in amount and decrease in alloying content with increasing aging temperature within this range. The small amount of highly enriched austenite formed from 620 to $660^{\circ} \mathrm{C}$ remained untransformed during cooling from the aging temperature. An example is shown in Fig. 16. ${ }^{26,27)}$ As the aging temperature increased, the newly formed austenite was observed to transform to bainite or martensite during cooling from the aging temperature, as the hardenability of the new austenite decreased with increasing aging temperature. A schematic overview of the aging behavior is presented in Fig. 17. ${ }^{26,27)}$

This study has helped clarify the role of copper in these steels:

(1) The $\mathrm{Cu}$ in solution at $900^{\circ} \mathrm{C}$ acts to increase the strength by lowering the $\mathrm{B}_{\mathrm{s}}$ or $\mathrm{M}_{\mathrm{s}}$ temperature, and by forming fine precipitates upon aging near $450^{\circ} \mathrm{C}$.

(2) The $\mathrm{Cu}$ precipitates act to retard the annealing of the bainitic or martensitic matrix thereby retaining high strength at higher aging temperatures.

(3) The amount of $\mathrm{Cu}$ in solution increases with aging
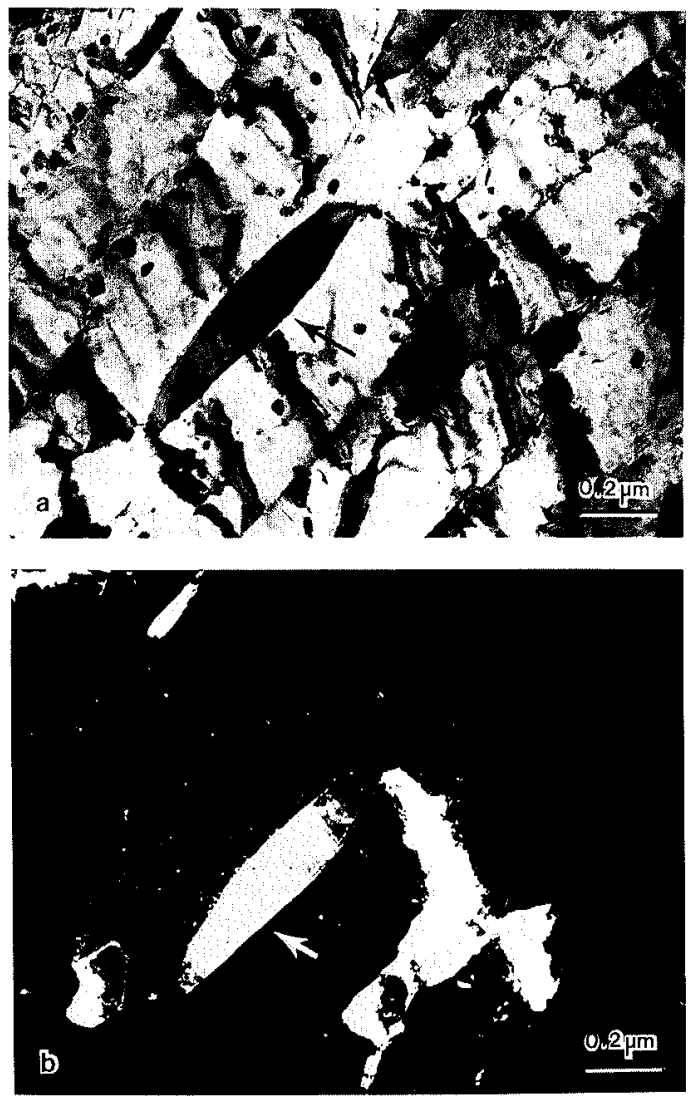

Fig. 16. TEM micrograph of thin foil of HSLA 100 aged at $665^{\circ} \mathrm{C} / \mathrm{l} \mathrm{h}$ shows newly formed austenite at lath boundary being retained after air cooling: a) $\mathrm{BF}$ image, b) DF image. ${ }^{26,27)}$ temperature. This leads to a lowering of the $\mathrm{Ac}_{1}$ which permits new austenite to form at lower aging temperatures, i.e. in a matrix that is still strong.

(4) The presence of the new austenite or its transformation products is related to the drastic improvement in low temperature toughness observed in Fig. 15. Various mechanisms have been suggested to explain this observation. ${ }^{26,27)}$ Perhaps the extra barriers to the growth of cleavage cracks offered by the new austenite or its transformation products is the most likely explanation.

The HSLA-100 steels offer another illustration where the presence of a small amount of a minor phase can have an appreciable influence on the overall properties of structural steels.

\section{Multi-phase Bar Steels}

The first use of multi-phase microstructures in bar and rod steels was described in $1983 .^{28)}$ The goal of that work was to replace the medium carbon low alloy steels which had to be treated to generate the required mechanical properties. These early workers found that low carbon $\mathrm{Mn}-\mathrm{Nb}-\mathrm{B}$ steel exhibited a dual-phase microstructure containing bainitic ferrite and MA microconstituent. Fasteners made from these steels were found to satisfy the French Standard NFE 27-005, Class 8-8 (YS= $627 \mathrm{MPa}, \mathrm{UTS}=780-980 \mathrm{MPa}$, and \% EL. $=9)$ and Class 10-9 (YS =882 MPa, UTS $=980-1176 \mathrm{MPa}$, and $\%$ EL. $=8$ ). In addition to eliminating the need for heat treatment, fasteners made from these steels appeared to be less susceptible to delayed or hydrogen cracking. ${ }^{28-30)}$

A later effort to investigate multi-phase steels for long product applications took a different approach. This research had the goal of developing a family of steels that could be used in either cold forging or hot forging applications. The optimum composition was a low carbon $\mathrm{Mn}-\mathrm{Mo}-\mathrm{Nb}$ steel which could be used for cold heading or cold forging applications in the as-controlled rolled condition, or for hot forging applications in the as-hot rolled condition. The as-controlled rolled microstructure consisted of a very fine mixture of ferrite of $5 \mu \mathrm{m}$ grain size and $20 \%$ lower bainite. ${ }^{31,32)}$ This steel has been called BHS-1.

Since the rate of work hardening was very high in the

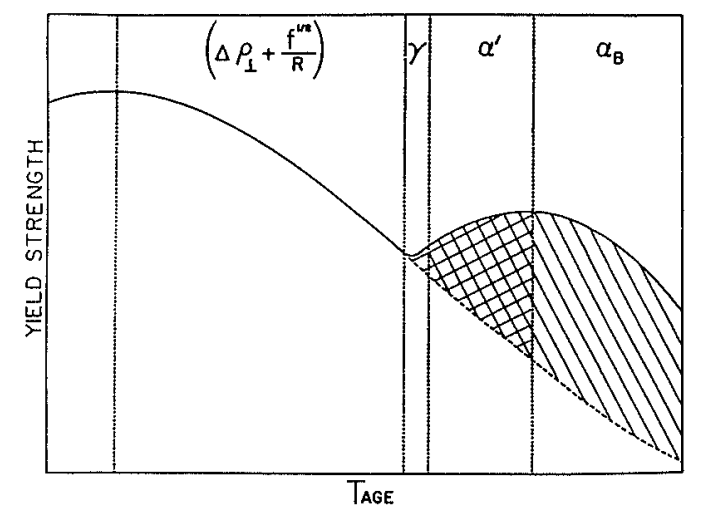

Fig. 17. Aging behavior of HSLA Cu-bearing steels. ${ }^{26,27)}$ 
as-controlled rolled multi-phase condition, the final component strength could be developed either through cold drawing or through cold forging. The mechanical properties of fasteners made from both standard low alloy steel and BHS-1 are shown in Table $2 .^{32,33)}$ The properties of the bolts made from BHS- 1 in the as-headed condition were the equivalent of those made from of the QT steel.

In another industrial trial, the properties of steering brackets made from BHS-1 and 1038 QT were compared, Tables 3 and $4 .^{32,33)}$ The tensile and impact properties of the brackets made from the multi-phase BHS-1 steel in the as-cold forged condition were superior to those made from the QT steel, Table 3. The fatigue properties of the brackets made from the two steels are shown in Table 4. The superior performance of the brackets cold forged from the multi-phase steel is obvious.

The same steel used in the cold forging trials is also well-suited for hot forging applications were high strength is required. In this case, two metallurgical re-

Table 2. Final bolt properties: production run.

\begin{tabular}{l|cccc}
\hline Steel & $\begin{array}{c}\text { YS } \\
(\mathrm{ksi})\end{array}$ & $\begin{array}{c}\text { UTS } \\
(\mathrm{ksi})\end{array}$ & $\begin{array}{c}\text { RA } \\
(\%)\end{array}$ & $\begin{array}{c}\text { CVN @ RT } \\
(\mathrm{ft-lbs})\end{array}$ \\
\hline GRADE 8 & 130 & 150 & 35 & - \\
1335 QT & 145 & 166 & 64 & 35 \\
BHS-1 & 140 & 168 & 67 & 43 \\
\hline
\end{tabular}

Table 3. Mechanical properties of steering brackets.

\begin{tabular}{l|rccc}
\hline Sample & $\begin{array}{c}\text { YS } \\
(\mathrm{ksi})\end{array}$ & $\begin{array}{c}\text { UTS } \\
(\mathrm{ksi})\end{array}$ & $\begin{array}{c}\text { RA } \\
(\%)\end{array}$ & $\begin{array}{c}\text { CVN @ RT } \\
\text { (ft-lbs) }\end{array}$ \\
\hline 1038 QT & 88 & 102 & 59 & 65 \\
BHS-1 & 120 & 150 & 43 & 71 \\
\hline
\end{tabular}

Table 4. Comparison of fatigue life properties.

\begin{tabular}{l|ccc}
\hline \multicolumn{4}{c}{ Fatigue cycle-to-failure data } \\
\hline Steel & $\begin{array}{c}\text { Average kilocycles- } \\
\text { to-failure }\end{array}$ & $\begin{array}{c}\text { Standard } \\
\text { deviation }\end{array}$ & $\begin{array}{c}\text { Expected life } \\
\text { kilocycles }\end{array}$ \\
\hline BHS & 261.85 & 46.94 & 169.57 \\
BC1038 & 134.79 & 36.54 & 62.96 \\
\hline
\end{tabular}

quirements were: (i) austenite grain refinement should occur during conventional forging practice, and (ii) a high strength microstructure should be developed during quenching from the trim dies. The composition of BHS-1 allows both of these requirements to be satisfied. The grain refinement occurs because of recrystallization controlled forging while the high strength occurs by the development of a multi-phase final microstructure of about $80 \%$ autotempered martensite and 20\% lower bainite. The fine austenite grain size and the mixed microstructure result in strong, though components. ${ }^{35}$ ) The mixed microstructure of autotempered lath martensite and lower bainite found in the specimen of BHS-1 steel direct quenched in oil from the forging temperature is shown in Fig. 18a. ${ }^{36)}$ Fine detail of these structures is shown in Fig. 18b. ${ }^{36)}$

An industrial trial was conducted to compare the properties of lower control arms forged from a low alloy steel that was to be heat treated and from BHS-1 in the direct quenched condition using either an Oil (OQ) or polymer (PQ) quench. The mechanical properties determined on specimens removed from the control arms are shown in Table 5. ${ }^{35}$ ) The properties of the BHS-1-OQ control arms are significantly higher than are those of the QT steel. Again, the difference in fatigue life is very large.

The benefits of multi-phase microstructures have, once again, been found in the bar and rod steel product line. Property improvement in both cold and hot forging applications have been realized through the use of these microstructures.

\section{Multi-phase Precipitates in Ultra-low Carbon Sheet Steels}

The ultra-low carbon or interstitial-free steels were

Table 5. Mechanical properties of lower control arms.

\begin{tabular}{c|rrrrrr}
\hline Sample & $\begin{array}{c}\text { YS } \\
(\mathrm{ksi})\end{array}$ & $\begin{array}{c}\text { UTS } \\
(\mathrm{MPa})\end{array}$ & $\begin{array}{c}\text { RA } \\
(\%)\end{array}$ & $\begin{array}{c}\text { CVN } \\
(\mathbf{J})\end{array}$ & $\begin{array}{c}\text { Average } \\
\text { kilocycles } \\
\text { to failure }\end{array}$ \\
\hline 1541H QT & 800 & 930 & 60 & 75 & 28 & 80000 \\
BHS (OQ) & 841 & 1047 & 66 & 74 & 43 & 280000 \\
BHS (PQ) & 779 & 1013 & 65 & 74 & 32 & 205000 \\
\hline
\end{tabular}

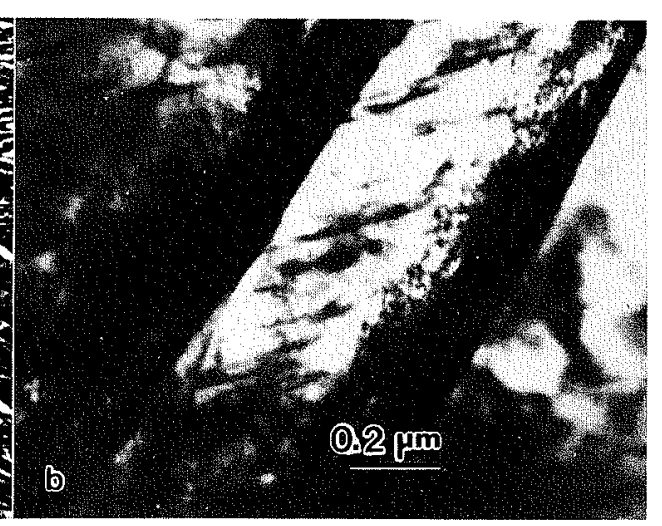

Fig. 18. Lower bainite and autotempered lath martensite in BHS-1 steel after RCF and DQ in oil. a) SEM, b) TEM. $^{36)}$ 
developed for enhanced deep drawability. This development was based on the observation of the inverse relationship between carbon content and deep drawability. ${ }^{37)}$ Whereas vacuum degassing of the liquid can lower the carbon content to $40 \mathrm{ppm}$ by weight, most of the remaining carbon must be removed through stabilization by the addition of strong carbide forming elements such as $\mathrm{Ti}$ and $\mathrm{Nb}$. Despite much research, questions remain concerning how this stabilization actually occurs. The design of current steels is based on stabilization occurring by the direct precipitation of $\mathrm{MN}, \mathrm{MC}$, or MCN. Recent work has shown that the stabilization of carbon does not occur in this way in all ULC steels. ${ }^{38-41)}$ The steels used in this recent work are shown in Table 6.

This work has shown that the stabilization occurs by a different mechanism in ULC steels where the atomic ratio of carbon to sulfur is near one. In this case, the carbon is initially and predominately removed from solid solution by the in-situ transformation of TiS to $\mathrm{Ti}_{4} \mathrm{C}_{2} \mathrm{~S}_{2}$. This reaction is then followed by the epitaxial precipitation of $\mathrm{MC}$ on the fully transformed $\mathrm{Ti}_{4} \mathrm{C}_{2} \mathrm{~S}_{2}$. No

Table 6. Composition of ULC steels. (wt\%)

\begin{tabular}{c|cccccccccc}
\hline Steel & $\mathrm{C}$ & $\mathrm{N}$ & $\mathrm{S}$ & $\mathrm{Ti}$ & $\mathrm{Nb}$ & $\mathrm{Mn}$ & $\mathrm{P}$ & $\mathrm{Al}$ & $\mathrm{Si}$ & $\mathrm{O}$ \\
\hline $\begin{array}{c}\mathrm{A} \\
\mathrm{Nb}+\mathrm{Ti} \\
\mathrm{B} \\
\begin{array}{c}\text { Ti-only } \\
\hline\end{array}\end{array}$ & .0026 & .003 & .006 & .060 & .030 & .11 & .007 & .043 & .003 & .002 \\
\hline
\end{tabular}
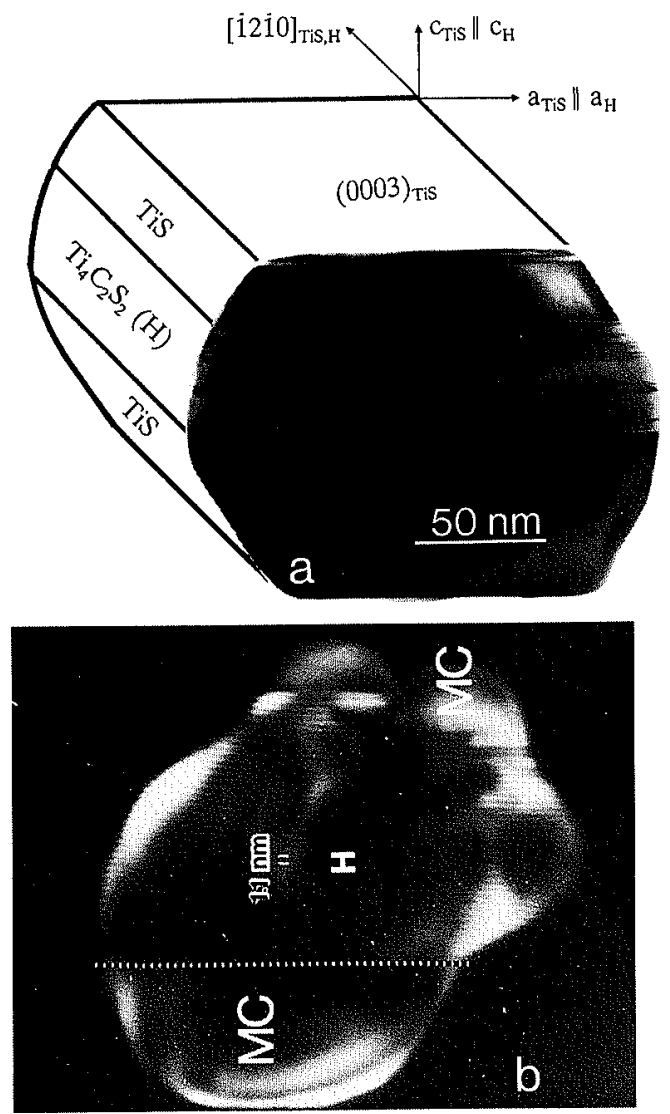

Fig. 19. Typical multi-phase sandwich-like particles observed in ULC steels. a) TiS-H-TiS, (40), b) MC-H-MC. ${ }^{42}$ independent precipitation of $\mathrm{MC}$ was observed, and all precipitation could be traced back to the original TiS particles, which may have formed on the deltaferrite from the interdendritic pools. Under conditions where the transformation of TiS to $\mathrm{Ti}_{4} \mathrm{C}_{2} \mathrm{~S}_{2}$ is incomplete, the resulting particles exhibit a multi-phase or sandwich-like structure in which the central layer region of the particle is $\mathrm{Ti}_{4} \mathrm{C}_{2} \mathrm{~S}_{2}$ and the outer layers are TiS. A typical sandwich-like particle is shown in Fig. 19a. ${ }^{40)}$ An example of the epitaxial precipitation of MC on the fully transformed $\mathrm{Ti}_{4} \mathrm{C}_{2} \mathrm{~S}_{2}$ is illustrated in Fig. 19b. ${ }^{42)}$

The results of this work call into question previous work on stabilization, and the alloy design of ULC steels. One view of stabilization holds that the carbon that is removed from solution leaves through the direct precipitation of MC, with no mention of the role played by sulfur. ${ }^{43)}$ While this may be true in very low sulfur steels $(<10 \mathrm{ppm} \mathrm{S})$, it has not been confirmed with advanced electron optical techniques. Furthermore, this view is certainly not true in the steels shown in Table 6. A second view of stabilization suggests that a significant portion of the carbon is removed from solution through the direct or independent precipitation of $\mathrm{Ti}_{4} \mathrm{C}_{2} \mathrm{~S}_{2} \cdot{ }^{44,45)}$ This suggestion differs from the observations made in the recent study ${ }^{38-42)}$ where the $\mathrm{Ti}_{4} \mathrm{C}_{2} \mathrm{~S}_{2}$ was observed to form directly from the pre-existing TiS.

The role played by $\mathrm{Nb}$ in the dual-stabilized steel, Steel $A$ in Table 6, appears to be quite surprising. Electron optical evidence ${ }^{40}$ ) has revealed that a small portion of $\mathrm{Nb}$ is present in the $(\mathrm{Ti}, \mathrm{Nb})_{4} \mathrm{C}_{2} \mathrm{~S}_{2}$, and that an additional small amount is found as ( $\mathrm{Ti}, \mathrm{Nb}) \mathrm{C}$ in the $\mathrm{MC}-\mathrm{M}_{4} \mathrm{C}_{2} \mathrm{~S}_{2}-$ MS sandwich-type particles, e.g. Fig. 19b. However, the major portion of the $\mathrm{Nb}$ was found to be present in solution on the ferrite grain and subgrain boundaries. ${ }^{42)}$ It is this $\mathrm{Nb}$ in solution that appears to be responsible for the stronger $\{557\}\left[\overline{12} \frac{19}{19} 5\right]$ textures and deep drawability found in the Nb-bearing stabilized steels. ${ }^{46)}$ Furthermore, the $\mathrm{Nb}$ in solution has been confirmed to be responsible for the enhanced resistance to powdering, bursting and cold work embrittlement often observed in single-stabilized Ti ULC steels. ${ }^{42)}$

The results of the recent study indicate that the alloy design of future ULC steels may follow a different path, at least concerning stabilization. In the future, the composition of the steel may reflect the precipitation that actually occurs. If that happens, then further improvements in the performance of these steels is possible.

\section{Concluding Remarks}

This paper has attempted to review a few examples of where multi-phase microstructures have shown new or improved properties. In some cases, the improvement in properties resulting from multi-phase microstructures were small and evolutionary in nature. In other cases, the improvements were starting and revolutionary. There is no question that this aspect of ferrous physical metallurgy is in its infancy, and that surprising new breakthroughs await future investigators. 


\section{REFERENCES}

1) A. Sauveur: The Metallography and Heat Treatment of Iron and Steel, 4th ed., McGraw-Hill, NY, (1935).

2) E. T. Sisco: Alloys of Iron and Carbon, Vol. II-Properties, McGraw-Hill, NY, (1937).

3) T. Gladman et al.: J. Iron Steel Inst., 208, (1970), 173.

4) K. J. Irvine: Low Alloy High Strength Steels, Metall. Co., Frese-Druck, Dusseldorf, (1970), 1.

5) L. Meyer et al:: Low Alloy High Strength Steels, Metall. Co., Frese-Druck, Dusseldorf, (1970), 9.

6) F. B. Pickering: Microalloying '75, Union Carbide Corp., New York, NY, (1977), 9.

7) I. G. Hamilton: Weldability of Structural and Pressure Vessel Steels, The Weld. Inst., (1970), 41.

8) B. A. Graville: Welding of HSLA (Microalloyed) Structural Steels, ASM, Metals Park, OH, (1978), 85.

9) T. Haze and S. Achara: Proc. 7th Int. Conf. on Offshore Mechanics and Arctic Eng., Houston, 7-11 February, (1988).

10) M. S. Rashid: SAE Preprint 760206, SAE, Warrendale, PA, (1976).

11) S. Hayami and T. Furukawa: Microalloying '75, Union Carbide Corp., New York, NY, (1977), 311

12) Formable HSLA and Dual-Phase Steels, TMS-AIME, Warrendale, PA, (1979).

13) Fundamentals of Dual-Phase Steels, TMS-AIME, Warrendale, PA, (1981).

14) M. S. Rashid: Formable HSLA and Dual-Phase Steels, TMS-AIME, Warrendale, PA, (1979), 1.

15) S. Hayami et al:: Formable HSLA and Dual-Phase Steels, TMS-AIME, Warrendale, PA, (1979), 169.

16) J. M. Rigsbee and P. J. VanderArend: Formable HSLA and Dual-Phase Steels, TMS-AIME, Warrendale, PA, (1979), 58.

17) A. P. Coldren et al:: Formable HSLA and Dual-Phase Steels, TMS-AIME, Warrendale, PA, (1979), 207.

18) M. Sudo et al.: Trans. Iron Steel Inst. Jpn., 21 (1981), 820.

19) M. Sudo et al.: Accelerated Cooling of Steel, TMS-AIME, Warrendale, PA, (1986), 501.

20) K. Amano et al:: Accelerated Cooling of Rolled Steel, Pergamon Press, New York, (1988), 43.

21) M. L. Brandt and G. B. Olson: Iron Steelmaker, 20 (1993), No. 5,55 .

22) A. J. DeArdo: Accelerated Cooling of Rolled Steel, Pergamon Press, New York, (1988), 3.

23) P. A. Peters and H. G. Hillenbrand: Microalloyed HSLA Steels, ASM Int., Materials Park, OH, (1988), 67.

24) W. M. Hof et al.: HSLA Steels: Metallurgy and Applications, ASM Int., Materials Park, OH, (1986), 467.

25) T. Montemarano et al.: J. Ship Production, 2 (1986), No. 3,
145.

26) M. Mujahid: University of Pittsburgh, Department of Materials Science and Engineering, M. S. Thesis, (1990).

27) M. Mujahid et al.: Processing, Microstructure and Properties of Microalloyed and Other Modern High Strength Low Alloy Steels, ISS-AIME, Warrendale, PA, (1992), 345.

28) B. Heritier et al.: HSLA Steels: Technology and Applications, ASM Int., Materials Park, OH, (1984), 981.

29) M. Kanao: Trans. Iron Steel Inst. Jpn., 22 (1982), 462.

30) F. Nakasato and F. Terasaki: Tetsu-to-Hagané, 61 (1975), 856.

31) C. I. Garcia et al.: 29th Mechanical Working and Steel Processing Conf., ISS-AIME, Warrendale, PA, (1987), 79.

32) C. I. Garcia et al.: 8th Process Technology Conf., Vol. 8, ISS-AIME, Warrendale, PA, (1988), 59.

33) C. I. Garcia et al.: SAE Technical Publication 910145, SAE, Warrendale, PA, (1991).

34) C. I. Garcia et al:: SME Technical Paper MF92-139, SME Cold Forming Technology Clinic, SME, Dearborn, MI, (1992).

35) C. I. Garcia et al:: SAE Technical Publication 910143, SAE, Warrendale, PA, (1991).

36) C. I. Garcia, A. K. Lis and A. J. DeArdo: Wire J. Int., (1991), 102.

37) D. J. Blickwede: Trans. ASM, 61 (1968), 653.

38) M. Hua, C. I. Garcia and A. J. DeArdo: Scr. Metall., 28 (1993), No. $8,973$.

39) M. Hua, C. I. Garcia and A. J. DeArdo: Proc. 51st Annual Meeting of MSA, ed. by G. W. Bailey and C. L. Reider, Microscopy Soc. of Amer., San Francisco Press, Inc. (1993), 744.

40) M. Hua, C. I. Garcia and A. J. DeArdo: Proc. Int. Symp. on Low Carbon Steels for the 90's, ed. by R. Asfahani and G. Tither, TMS, (1993), 445 .

41) M. Hua, C. I. Garcia and A. J. DeArdo: Proc. Third Int. Conf. on Solid $\rightarrow$ Solid Phase Transformations in Inorganic Materials, PTM94, July 17-22, (1994), Nemacolin Woodland Resort, Pittsburgh, TMS, Warrendale, PA, in press.

42) G. Tither, et al: Int. Forum for Physical Metaliurgy of IF Steels, ISIJ, Tokyo, (1994), 293.

43) D. O. Wilshynsky-Dresler, D. K. Matlock and G. Krauss: Int. Forum for Physical Metallurgy of IF Steels, ISIJ, Tokyo, (1994), 13.

44) A. Okamato and N. Mizui: Metallurgy of Continuously Annealed Sheet Steel, ed. by B. L. Bramifitt and P. C. Mangonon, Jr., TMS-AIME, Warrendale, PA, (1982), 161

45) S. V. Subramanian et al:: Interstitial Free Steels: Processing, Fabrication and Properties, Proc. Int. Sym., ed. by L. E. Collins and D. L. Baragar, Canadian Inst. of Mining, Metallurgy and Petroleum, Ottawa, (1991), 15.

46) R. E. Hook: Metallurgy of Vacuum-Degassed Steel Products, ed. by R. Pradhan, TMS-AIME, Warrendale, PA, (1990), 263. 